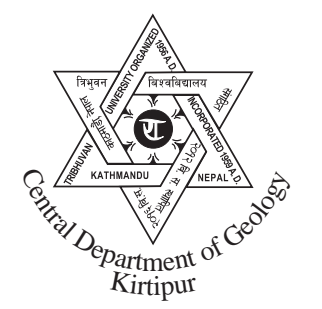

\title{
Shallow soil slope instability analyses at horticultural farm, Daman, Central Nepal
}

\author{
Suman Manandhar \\ Central Department of Geology, Tribhuvan University, Kathmandu, Nepal
}

\begin{abstract}
Slope stability analyses were carried out for slopes around the horticultural farm at Daman, Central Mahabharat Region of Nepal. Daman lies in the Mahabharat zone with intruded granite as the basement rock. These granites are highly to completely weathered and decomposed to few metres depth from the exposed surfaces. The horticultural farm is situated over these decomposed rocks with some colluvium along the hill slopes. The rainstorm of 19-21 July 1993 devasted the horticultural farm with numerous landslides and gully erosions. Based on the limit equilibrium analysis theory and computed index as well as strength properties of the soil, analyses of three of the failed slopes were carried out. The analyses revealed that slides were unstable only during fully saturated conditions.
\end{abstract}

\section{INTRODUCTION}

The horticultural farm is situated on the ridge of Daman at an altitude of about $2300 \mathrm{~m}$ along the Tribhuvan Highway. It lies south of the Kathmandu Valley in the Maharabharat Zone, Central Development Region of Nepal (Fig. 1).

The Daman ridge is formed of intruded granite that has been highly to completely weathered to certain depth. It is subject to numerous landslides and gully erosion (Manandhar 2000). Besides, the unprecedented rainstorm of 19-21 July 1993 affected the entire area with numerous landslides and gully erosion. These landslides were caused due to smallscale shallow slope failures. The slope instability analyses of the slopes were carried out to find the factor of safety of the slopes during dry and fully saturated conditions.

\section{GEOLOGICAL SETTING}

The Daman area comprises of the Palung granite intruded in the Bhimphedi Group of rocks (Stöklin

Corresponding author:

E-mail address: geosuman@gmail.com and Bhattarai 1981). These granites are highly to completely weathered and have converted to yellow brown soil. However, along the streambeds, granites are moderately weathered and closely jointed. The granite constitutes quartz, plagioclase, biotite, and perthite as essential minerals with few tourmalines. These minerals are small-grained (less than $3 \mathrm{~mm}$ ).

\section{LANDSLIDES AND GULLY EROSION}

There are about 73 landslides and 12 gullies within a total area of 51,600 $\mathrm{m}^{2}$. The total rock/soil displaced was $34,100 \mathrm{~m}^{3}$ of which the landslide had displaced $31,800 \mathrm{~m}^{3}$ and gully erosion had displaced $2,300 \mathrm{~m}^{3}$. The area covered by landslides is $11,650 \mathrm{~m}^{2}$. The average depth of failure is $0.8 \mathrm{~m}$ (Dhital et al. 1993). The soil depth of the area ranges from $<1$ to $>6 \mathrm{~m}$. The average depth is about $3 \mathrm{~m}$. Descriptions of studied landslides in the horticultural farm are given in Table 1.

\section{METHODS}

Geotechnical properties were computed to find strength parameters of soil slopes for computational analyses. Factor of safety of translational and rotational soil slopes were determined. 


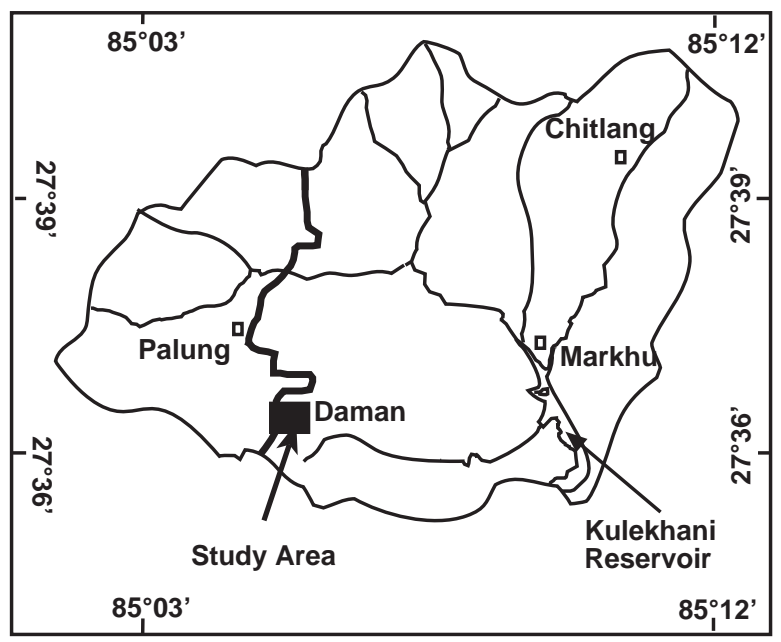

Fig. 1 Location map of study area

\section{Stability Analyses of Infinite Slopes}

Translational slide often initiates without any significant change in geometry of the unstable region. An 'infinite slope' denotes a uniform slope of an extent large enough that a typical element can be considered representative of the slope as a whole, and irregularities at the toe and the crest of the slide can be ignored. The soil properties and porewater pressures at any given distance below the ground surface were assumed to be constant (Graham 1984). When the depth to a planar surface was small compared with length, the stability was analyzed as an infinite slope.

If a typical slide of depth $\mathrm{z}$ and width $\mathrm{b}$ bounded by the vertical lines IJ and KL is isolated for attention, then from considerations of continuity it follows that the resultant forces $Q_{L}$ and $Q_{r}$ on the sides of the slice must be equal, opposite and collinear (Fig. 2). The vertical force across the base of the slice must equal weight $\mathrm{W}$ which can be resolved into normal (P) and tangential (T) components. For stability, the downslope shear stress must not exceed the shear strength of the clay. The safety factor in the slope can be defined in terms of effective stresses by the ratio, $\mathrm{f}$ that is:

$$
\mathrm{F}=\left\{\left(\mathrm{C}^{\prime}+\left({ }_{\mathrm{w}}\right) \tan { }^{\prime}\right\} / \tan \right.
$$

If the groundwater level is at the slope surface $(m=1)$, and soil is cohesionless $\left(C^{\prime}\right)$ is zero then

$$
\mathrm{F}=\left\{\left(-_{\mathrm{w}}\right) \tan ,\right\} / \tan
$$

For dry condition, unit weight of water $\left({ }_{w}\right)$ becomes zero, the equation (2) becomes as follows:

$$
\mathrm{F}=\tan \prime / \tan
$$

\section{Simplified Janbu method for finite slopes}

The 'finite slope' is used to designate a nonuniform slope. There are number of elements and irregularities. Such slopes may expose curvilinear rather than planar to the surface (Graham 1984). Fig. 3 shows a potential sliding surface with centre $\mathrm{O}$ and radius $\mathrm{R}$ (Graham 1984). Water on the left and right of the section produces moments $\mathrm{A}_{1} \mathrm{a}_{1}$ and $\mathrm{A}_{\mathrm{r}} \mathrm{a}_{\mathrm{r}}$. The slide mass is divided into slices by vertical planes and a typical slice IJKL is shown. The method assumes that the resultant forces $\mathrm{Q}_{\mathrm{L}}$ and $\mathrm{Q}_{\mathrm{r}}$ on IJ and $\mathrm{KL}$, respectively are equal and opposite and parallel to the base of the slice JK.

The simplified Janbu method was used to determine the stability of the slide mass. The method describes a relatively simple analysis for generalized slide surfaces which neglects the interslice forces in the expression for P. It satisfies vertical force equilibrium for each slice, as well as overall horizontal force equilibrium for the entire slide mass. The factor of safety for fully saturated soil mass was calculated using the following expression (Graham 1984):

$$
F_{C}=\frac{{ }_{i=1}^{i=N}\left[\begin{array}{cc}
c^{\prime} b+\left(\begin{array}{ll}
W_{i} & u b
\end{array}\right) \tan \quad
\end{array}\right] \frac{\mathrm{sec}}{m}}{\substack{i=N \\
i=1}}
$$

During dry condition, porewater (u) was zero and the equation (5) as given below was used.

$$
F_{c}=\frac{{ }_{i=1}^{i=N}\left[c^{\prime} b+\quad W_{i} \tan { }^{\prime}\right] \frac{\sec }{m}}{\begin{array}{l}
i=N \\
i=1
\end{array} W_{i} \tan }
$$

Where,

$$
m=\cos \left[1+\frac{\tan \tan }{F}\right]
$$

The reported Janbu safety factor $\mathrm{F}$ was determined by multiplying calculated safety factor $F_{c}$ by a 


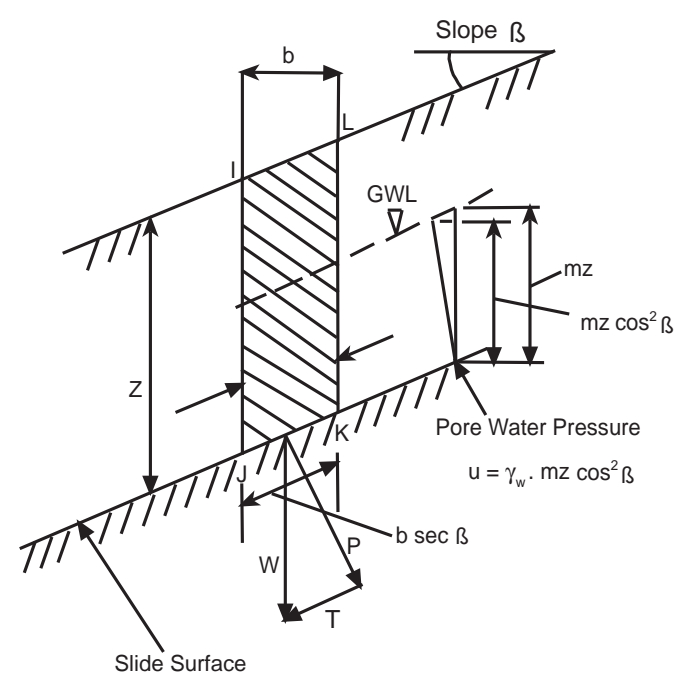

Fig. 2 Planar failure in infinite slope (based on Graham 1984)

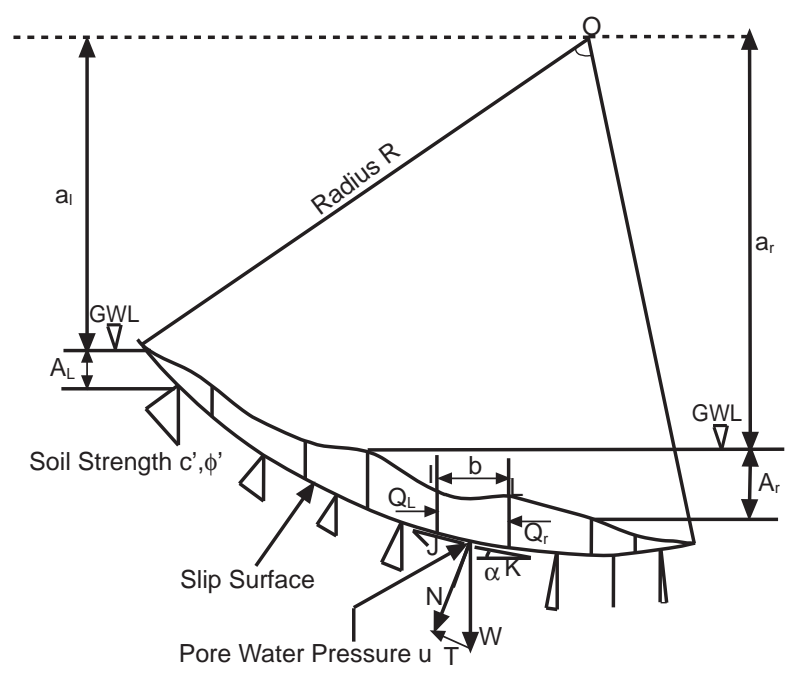

Fig. 3 Circular arc sliding surface in finite slope illustrating the elements of modified Janbu method

modification factor $\mathrm{f}_{0}$, then:

$$
\mathrm{F}=\mathrm{f}_{0} \times \mathrm{F}_{\mathrm{c}}
$$

This modification factor that is a function of the slide geometry and the strength parameters of the soil was obtained from slope geometry and soil type.

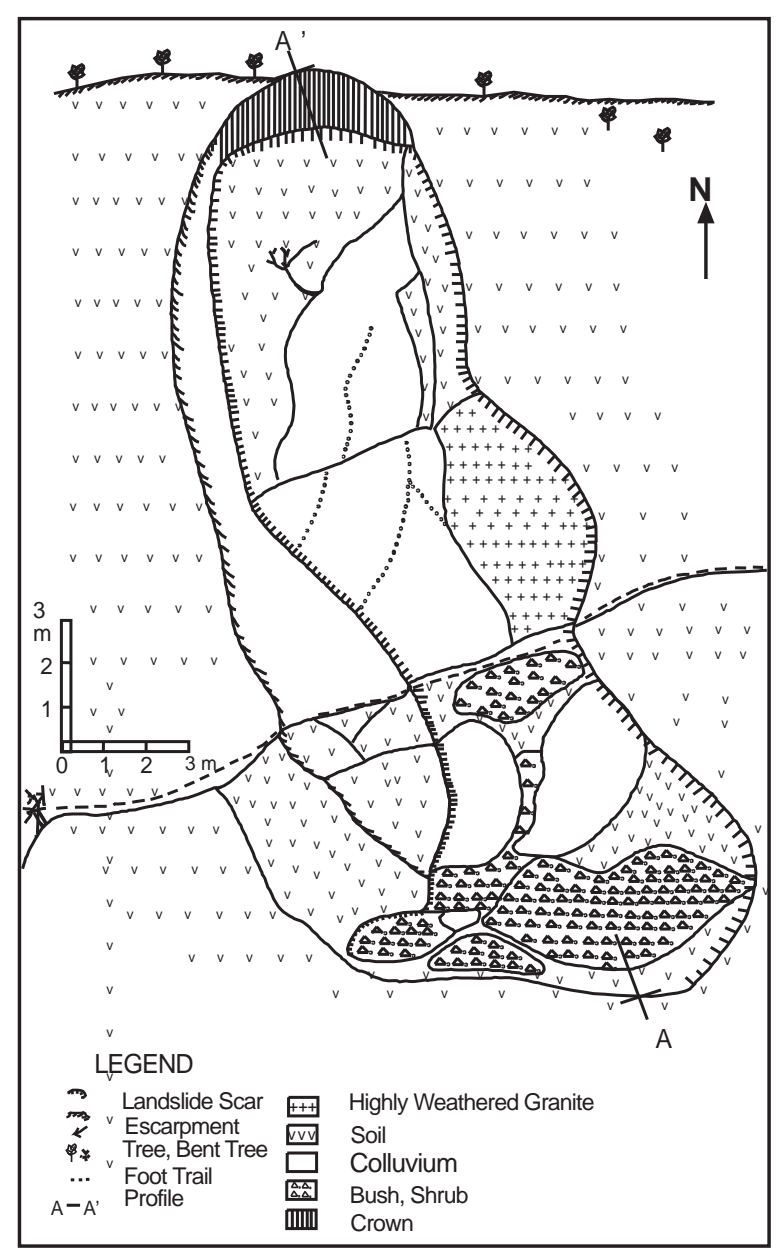

Fig. 4 Sketch of the translational soil slide SL-1 at the Horticultural Farm, Daman

The parameters, $\mathrm{d}$ and $\mathrm{L}$ were substitued for slope geometry where they belonged to depth of slide and length of slope profile. For convenience, this modification factor was computed using the equation (8) below:

$$
f_{0}=1+\mathrm{b}_{1}\left[\frac{\mathrm{d}}{\mathrm{L}}-1.4\left(\frac{\mathrm{d}}{\mathrm{L}}\right)^{2}\right]
$$

Where, $b_{1}$ varied according to the soil type. Values of $b_{1}$ was 0.69 when $=0$, that was when there was cohesion only. Similarly, $b_{1}$ was 0.31 and 0.50 when $c^{\prime}=0$ and ' $=0, c^{\prime} \quad 0$ conditions, respectively (Abramson et al. 2002). 


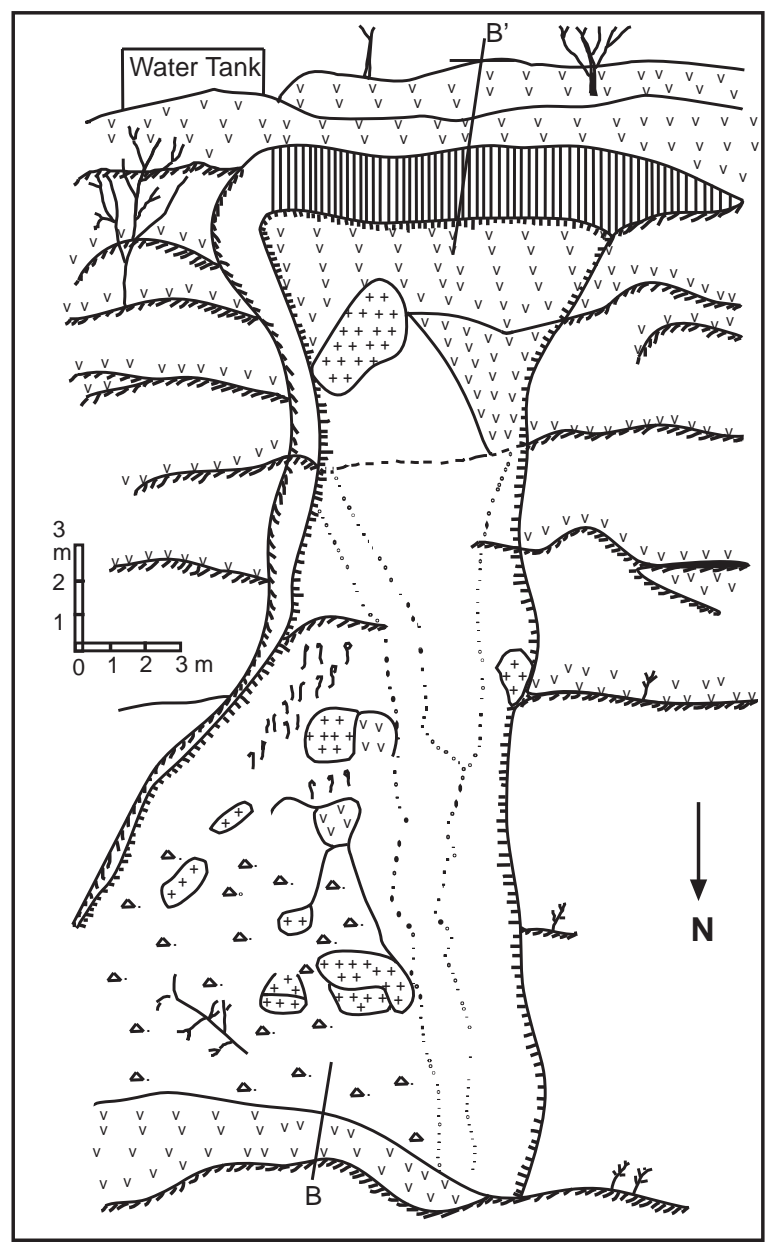

Fig. 5 Sketch of the translational soil slide SL-2 at the Horticultural Farm, Daman (see legend in Fig. 4)

Equations (4) and (5) include the calculated factor of safety on both sides of the equation. A trial value of $F$ was first assumed and the safety factor was computed until its value coincided with $F$.

For the stability analysis, circle of radius of 81.5 $m$ was constructed passing through the crown and toe of the slide assuming a slip circle. Then whole block was split up 8 unequal parts for the determination of safety factor. The slip circle was assumed with displaced material from the crown to the toe.

\section{Geotechnical Properties of the Soil}

Field identification was used to identify the soil types and to find out the relative densities of noncohesive soils. Natural moisture content, particle

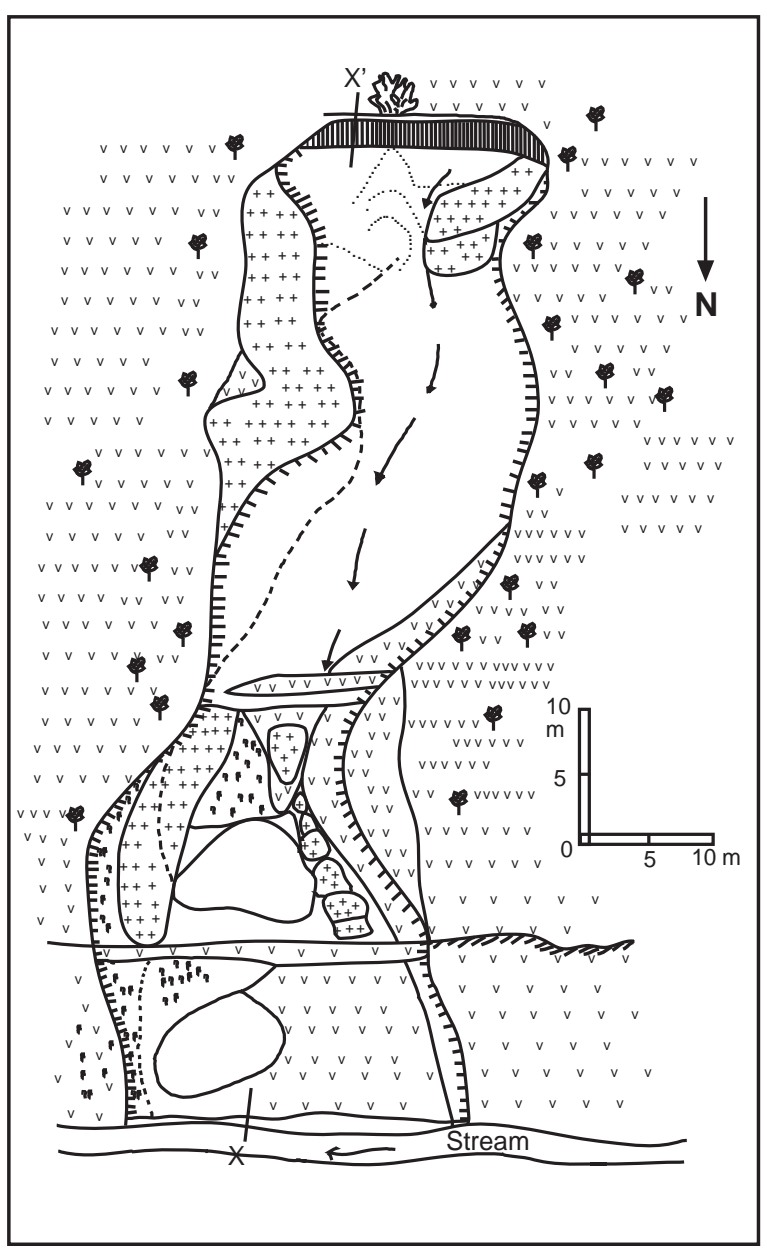

Fig. 6 Sketch of the translational soil slide SL-3 at the Horticultural Farm, Daman (see legend in Fig. 4)

diameter, specific gravity, unit weights, and strength parameters of the soil were obtained by laboratory tests on collected soil samples.

At first, the samples were air-dried and natural moisture contents were determined. Then, particle size distributions of soils were plotted in the semilog graph paper and specific gravity was computed thoroughly. The strength parameters were obtained by direct shear tests performed in a remolded soil specimen of $6 \mathrm{~cm} \times 6 \mathrm{~cm} \times 4 \mathrm{~cm}$ size with predetermined normal stresses equivalent to the overburden pressure and shearing rate of 0.01 $\mathrm{mm} /$ minute under drained condition. The angle of internal friction and cohesion parameters were found at the residual state to analyze the stability analyses of slopes. 
Shallow soil slope instability analyses at horticultural farm, Daman, Central Nepal

Table 1. Description of the landslides in the Horticultural Farm, Daman

\begin{tabular}{|c|c|c|c|c|c|c|c|c|c|c|c|c|}
\hline Location & $\begin{array}{l}\text { Types } \\
\text { of slide }\end{array}$ & $\begin{array}{l}\text { Length } \\
(\mathrm{m})\end{array}$ & $\begin{array}{r}\text { Width } \\
(\mathrm{m})\end{array}$ & $\begin{array}{c}\text { Depth } \\
\text { (m) }\end{array}$ & $\begin{array}{l}\text { Area } \\
\left(\mathrm{m}^{2}\right)\end{array}$ & $\begin{array}{c}\text { Sediment } \\
\text { produced } \\
\left(\mathrm{m}^{3}\right)\end{array}$ & $\begin{array}{l}\text { Natural } \\
\text { slope } \\
\text { (Degree) }\end{array}$ & $\begin{array}{l}\text { Failed } \\
\text { slope d } \\
\text { (Degree) }\end{array}$ & $\begin{array}{l}\text { Slope } \\
\text { direction }\end{array}$ & $\begin{array}{l}\text { Width of } \\
\text { tension } \\
\text { crack. } 10^{-2} \mathrm{~m}\end{array}$ & $\begin{array}{l}\text { Main } \\
\text { cause }\end{array}$ & Damage \\
\hline $\begin{array}{l}\text { Daman } \\
\text { SL-1 }\end{array}$ & $\begin{array}{l}\text { Translatic } \\
\text { soli slide }\end{array}$ & onal 24 & 9 & 1.3 & 170 & 221 & $26^{\circ}$ & $30^{\circ}$ & SE & $0.022-0.04$ & $\begin{array}{l}\text { Porewater } \\
\text { pressure }\end{array}$ & $\begin{array}{l}\text { Horticultural } \\
\text { Farm and forest }\end{array}$ \\
\hline $\begin{array}{l}\text { Daman } \\
\text { SL-2 }\end{array}$ & $\begin{array}{l}\text { Translatic } \\
\text { soli slide }\end{array}$ & onal $_{23}$ & 14 & 1.7 & 218.07 & 370.719 & $20^{\circ}$ & $28^{\circ}$ & $\mathrm{NE}$ & $0.02-0.05$ & $\begin{array}{l}\text { Porewater } \\
\text { pressure }\end{array}$ & $\begin{array}{l}\text { Horticultural } \\
\text { Farm and forest }\end{array}$ \\
\hline $\begin{array}{l}\text { Daman } \\
\text { SL-3 }\end{array}$ & $\begin{array}{l}\text { Circular } \\
\text { soli slide }\end{array}$ & 88 & 28 & 3.0 & 1739.0625 & 3586.125 & $22^{\circ}$ & $26^{\circ}-35^{\circ}$ & $\mathrm{NE}$ & $0.03-0.09$ & $\begin{array}{l}\text { Porewater } \\
\text { pressure }\end{array}$ & $\begin{array}{c}\text { Horticultural } \\
\text { Farm and forest }\end{array}$ \\
\hline
\end{tabular}

Table 2: Geotechnical properties of soil

\begin{tabular}{cccclcc}
\hline $\begin{array}{c}\text { Sample } \\
\text { number }\end{array}$ & $\begin{array}{c}\text { Natural moisture } \\
\text { content }(\mathrm{w} \%)\end{array}$ & $\begin{array}{c}\text { Specific } \\
\text { gravity }\end{array}$ & $\begin{array}{c}\text { Relative density } \\
(\%)\end{array}$ & $\begin{array}{c}\text { Unified soil classification } \\
\text { system }\end{array}$ & $\begin{array}{c}\text { Cohesion } \\
\left(\mathrm{kNm}^{-2}\right)\end{array}$ & $\begin{array}{c}\text { Angle of internal } \\
\text { friction }\left({ }^{\circ}\right)\end{array}$ \\
\hline SL-1 & 15.19 & 2.653 & $50-70$ & Well graded sand & 0.0 & 35 \\
SL-2 & 20.861 & 2.67 & $50-70$ & Poorly graded sand & 0.0 & 36 \\
SL-3 & 14.009 & 2.652 & $50-70$ & Poorly graded sand with few fines & 5.0 & 33 \\
\hline
\end{tabular}

\section{CHARACTERISTICS OF SOIL SLOPES}

The soil slopes SL-1 (Fig. 4) and SL-2 (Fig. 5) are situated at the northeast and south of the horticultural Farm. Slope SL-1 is concave in nature while slope SL-2 is concave from crown to $7 \mathrm{~m}$ downslope and remaining portion is convex in nature. Lengths and widths of both slopes are $24 \mathrm{~m}, 9 \mathrm{~m}$ and $23 \mathrm{~m}, 14 \mathrm{~m}$ respectively. The south facing and north facing slopes have $26^{\circ}$ and $20^{\circ}$ natural slope $30^{\circ}$ and $28^{\circ}$ when failed. The failed slopes are almost parallel to the natural slope forming translational soil slide. Few tension cracks were observed at the top part of the slide and were measured to be $20 \mathrm{~mm}$ to $40 \mathrm{~mm}$ wide and $20 \mathrm{~mm}$ to $50 \mathrm{~mm}$ wide in both slopes (Table $1)$.

The soil slope SL-3 (Fig. 6) is situated at the south of the farm. The soil slope is concave in the upper part and convex at the mid-part. A stream is flowing from west to east near the toe of the slope. Length and width of the slope are $88 \mathrm{~m}$ and $28 \mathrm{~m}$, respectively. The south facing slope has $22^{\circ}$ natural slope and forms variable slopes ranging from $26^{\circ}-35^{\circ}$ after slide. Tension cracks of width from $30 \mathrm{~mm}$ to 90 $\mathrm{mm}$ were observed at the top part (Table 1).

\section{RESULTS}

The first event of landslide was occurred due to continuous precipitation on 19-21 July 1993. The entire area of Daman and horticultural farm was affected through several landslides and gully erosions. Numerous small-scale shallow soil slides occurred in mostly residual soil of granite and affected the farm and forest.

Since both infinite and finite slopes of low depth of failure exist, the stability conditions of them were computed. To determine the factor of safety, geotechnical properties were determined. Soil slope SL-1 was well graded sand while SL-2 and SL-3 were well graded and poorly graded sands (Fig. 7). Specific gravity varied from 2.652 to 2.67 (Table 2). Relative density was 50-70\% for all three samples. Direct shear test results of two samples SL-1 and SL-

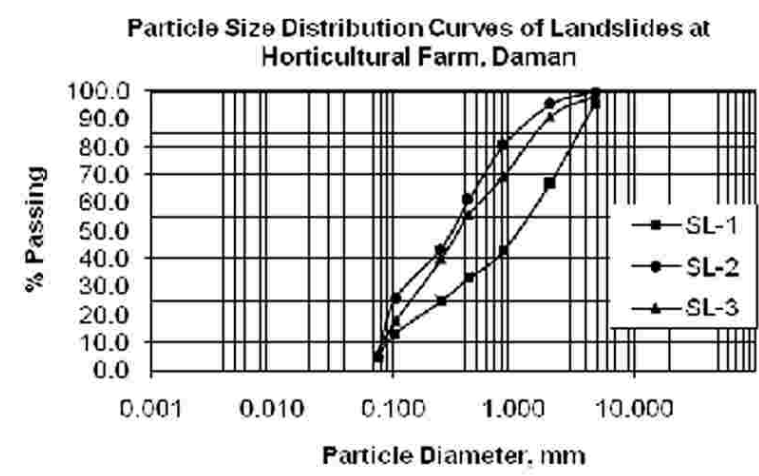

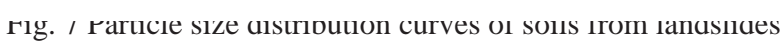
at the Horticulture Farm 


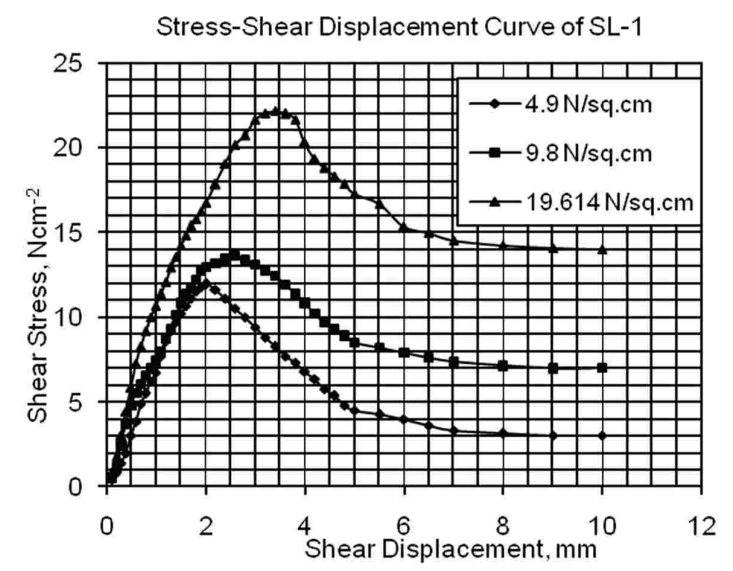

(a)

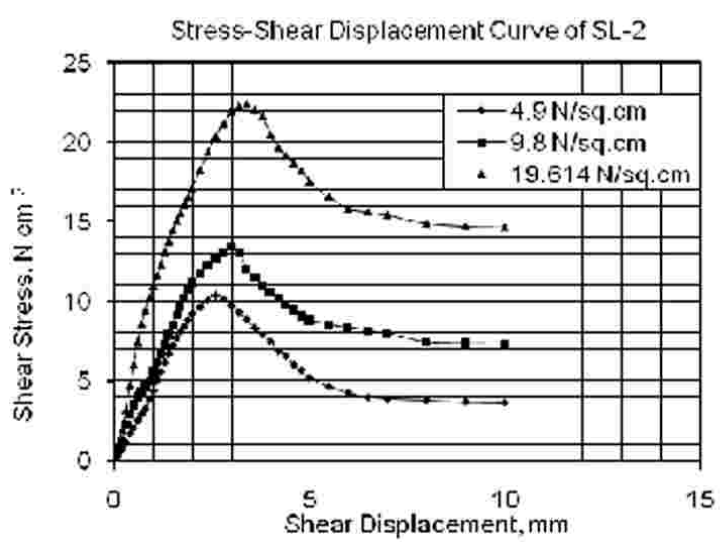

(b)

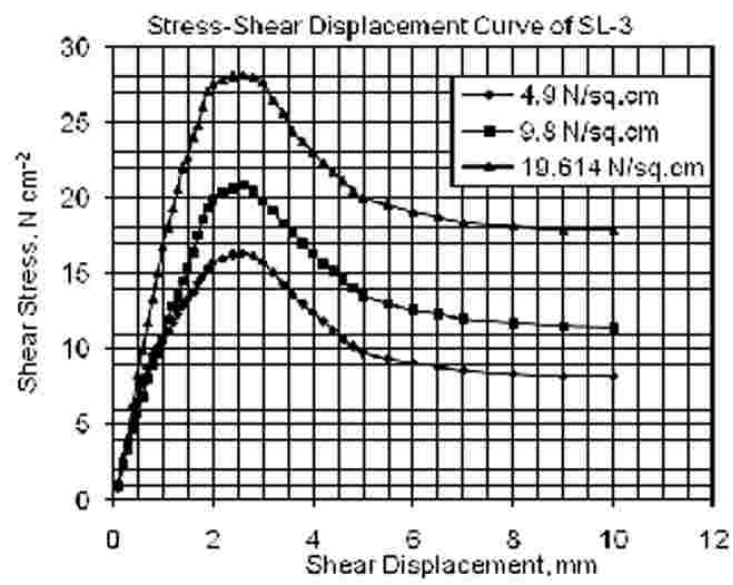

(c)

Fig. 8 (a) Stress-shear displacement curve of SL-1 infinite soil slope, (b) Stress-shear displacement curve of SL-2 infinite soil slope and (c) Stress-shear displacement curve of SL-3 finite soil slope

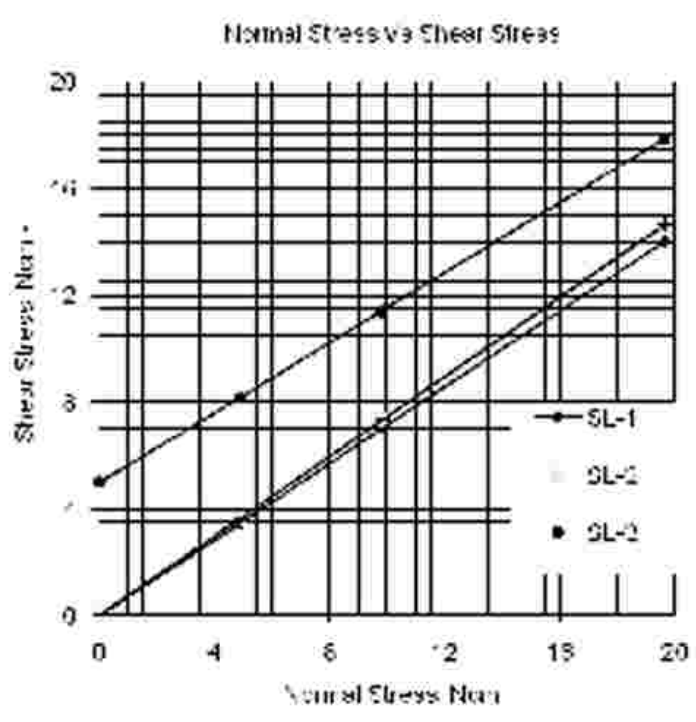

Fig. 9 Normal stress and shear stress curve to determine cohesion and angle of internal friction

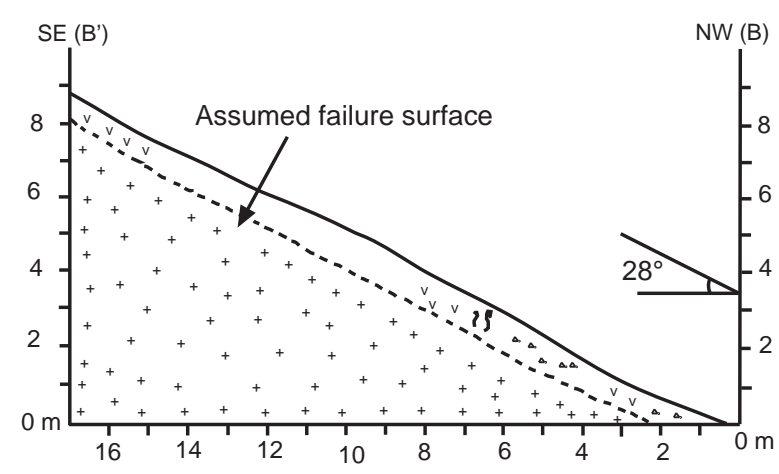

Fig. 10 Profile of the translational soil slide SL-1 along A-A' in Fig. 4

2 were non-cohesive with angle of internal frictions of $35^{\circ}$ and $36^{\circ}$ respectively. Instead, SL-3 showed little cohesion of $5 \mathrm{kNm}^{-2}$ with angle of internal friction $33^{\circ}$ (Figs. 8 and 9).

Angle of internal friction, cohesion, unit weight, and depth of failure were the essential parameter which were used for finding the stability condition. The profiles of SL-1 and SL-2 indicated infinite slopes (Figs. 10 and 11). The Infinite slope analyses of SL-1 and SL-2 showed stable during dry season (Table 3). Factors of safety of them were computed 
as 1.219 and 1.366. In fully saturated condition, slopes showed unstable and the factors of safety reduced to 0.647 and 0.654 (Table 3). Similarly, profile of SL-3 indicated circular nature (Fig. 12). The finite slope analysis using simplified Janbu method showed that the factor of safety exceeded unity (Table 5). The factor of safety during dry season was 1.575 . Assuming fully saturated condition, factor of safety declined to 0.612 (Table 6). Since, factor of safety of all soil slopes revealed stable during dry periods and unstable while saturated, the continuous precipitation were responsible to disturb such soil slopes around the horticultural farm.

Proper water drainage is the most important technique for the correction or prevention of landslides. Temporary remedial measures should be considered to divert water runoff from failure zone or sealing cracks with surface coatings to reduce water infiltration or covering the ground surface temporarily. Surface runoff should be diverted away from the slide mass as a permanent solution. The channels should be placed at the head of the slope and along berms. Then, vegetation (grass and shrubs) should be planted to stabilize to slopes for long term basis.

\section{CONCLUSION}

The results of stability analyses of the slopes indicated that slopes were only unstable during fully saturated conditions. The high precipitation during the unprecedented rain in July 19-21, 1993 fully saturated the top soil layers in Daman area which caused the slope failures. Based on the nature of the slope instabilities, the most suitable and economical preventive measures such as surface drainage work and vegetative practices are recommended for safer slopes.

\section{ACKNOWLEDGEMENTS}

Author is thankful to the Central Department of Geology for providing necessary material to prepare this paper. Author is also thankful to U. B. Shrestha, Department of Mines and Geology and M. S. Dhar, Institute of Engineering for providing comments on this paper.

\section{REFERENCES}

Abramson, L.W., Lee, T.S., Sharma, S., and Boyce, G.M.,

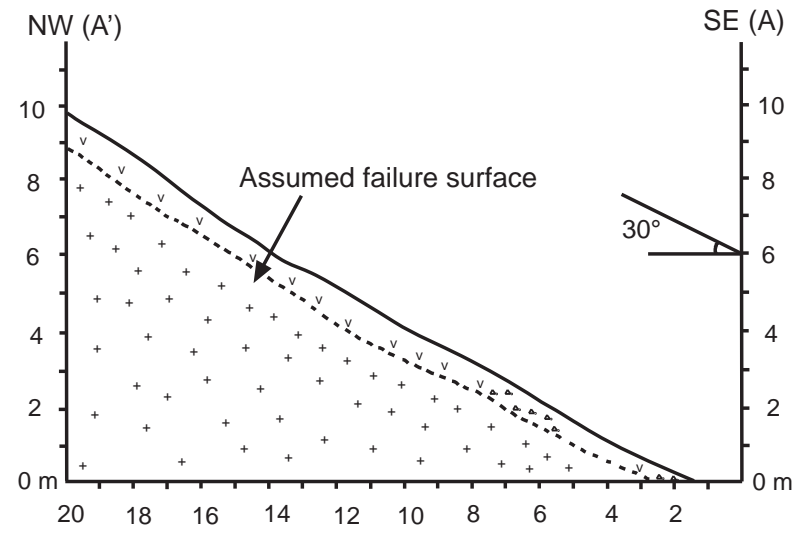

Fig. 11 Profile of the translational soil slide SL-2 along B-B' in Fig. 5

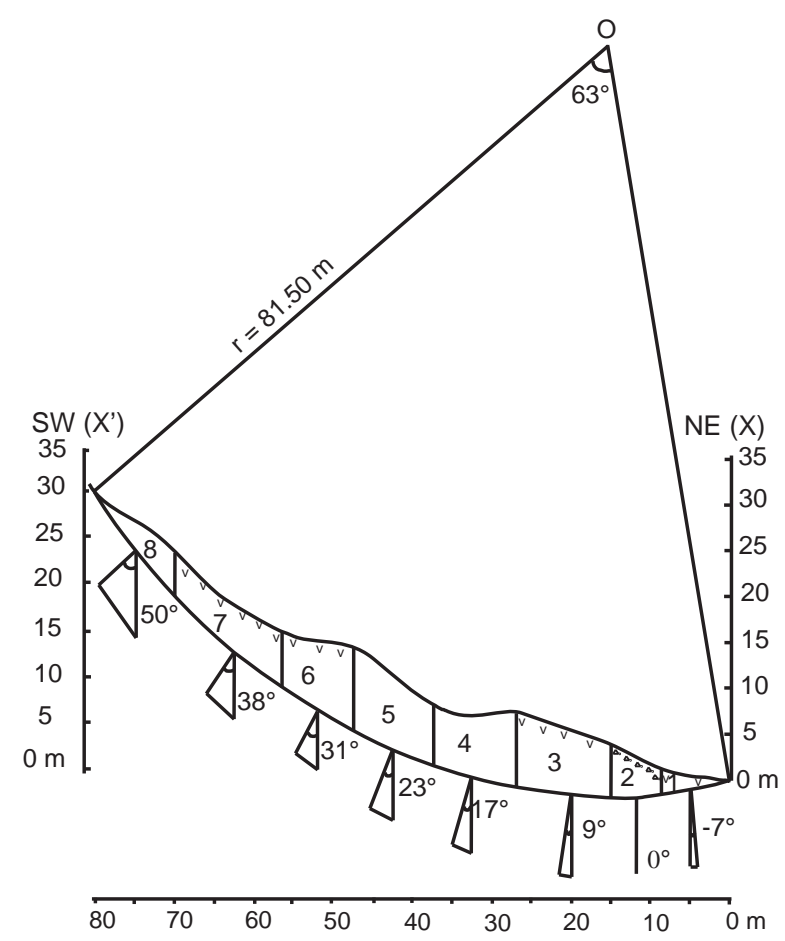

Fig. 12 Profile of the translational soil slide SL-3 along X-X' in Fig. 4

2002. Slope Stability and Stabilization Methods, Second Edition, A Wiley-Interscience Publication, John Wiley \& Sons, Inc., 712p.

Dhital, M.R., Khanal, N., and Thapa, K.B., 1993. The Role of Extreme weather Events, Mass Movements, and Land Use changes in Increasing Natural Hazards. A report of the preliminary Field Assessment and workshop on causes of the Recent Damage Incurred in 
Table 3: Stability analyses of infinite soil slopes, SL-1 and SL-2

\begin{tabular}{lcc}
\hline \multicolumn{1}{c}{ Parameters } & SL-1 & SL-2 \\
\hline Unit weight at $\mathrm{w}_{\mathrm{N}}$ moisture content, $\quad, \mathrm{kN} / \mathrm{m}^{3}$ & 18.8 & 21.79 \\
Unit weight of water, ${ }_{\mathrm{w}} \mathrm{kN} / \mathrm{m}^{3}$ & 9.81 & 9.81 \\
$\mathrm{~b}=-{ }_{\mathrm{w}}, \mathrm{kN} / \mathrm{m}^{3}$ & 8.99 & 11.98 \\
Depth of slide, $\mathrm{H}_{\mathrm{R}}, \mathrm{m}$ & 1.3 & 1.7 \\
Angle of landslide profile with horizontal, & $30^{\circ}$ & $28^{\circ}$ \\
In Dry Condition & & 1.366 \\
Factor of Safety, F (Equation (3)) & 1.219 & 0.654 \\
In Fully Saturated Condition & & 0.647 \\
Factor of Safety, F (Equation (2))
\end{tabular}

Table 4: Representation of Slice data for finite soil slope

\begin{tabular}{ccccccccccc}
\hline $\begin{array}{c}\text { Slice } \\
\text { No. }\end{array}$ & $\begin{array}{c}\mathrm{b} \\
(\mathrm{m})\end{array}$ & $\begin{array}{c}\mathrm{h}_{\mathrm{i}} \\
(\mathrm{m})\end{array}$ & $\begin{array}{c}\mathrm{c}^{\prime} \\
(\mathrm{kPa})\end{array}$ & $\begin{array}{c}\mathrm{c} \\
(\mathrm{deg})\end{array}$ & $(\mathrm{deg})$ & & $\begin{array}{c}\mathrm{W}_{\mathrm{i}} \\
(\mathrm{KN})\end{array}$ & $\begin{array}{c}\mathrm{u}=\mathrm{wh}_{\mathrm{i}} \\
(\mathrm{KN})\end{array}$ & $\begin{array}{c}\mathrm{W}_{\mathrm{i}} \sin \\
(\mathrm{KN})\end{array}$ \\
\hline 1 & 8.5 & 2.5 & 5.0 & 33 & -7 & 42.5 & 205.0 & 212.5 & -24.983 \\
2 & 6.5 & 5.75 & 5.0 & 33 & 0 & 32.5 & 520.0 & 373.75 & 0.000 \\
3 & 12.0 & 8.0 & 5.0 & 33 & 9 & 60.0 & 1380.0 & 960.00 & 193.197 \\
4 & 10.5 & 6.25 & 5.0 & 33 & 17 & 52.5 & 1235.0 & 656.25 & 361.079 \\
5 & 10.0 & 9.5 & 5.0 & 33 & 23 & 60.0 & 1600.0 & 950.00 & 625.170 \\
6 & 9.0 & 6.0 & 5.0 & 33 & 31 & 45.0 & 1375.0 & 540.00 & 708.177 \\
7 & 13.5 & 5.25 & 5.0 & 33 & 38 & 67.5 & 1325.0 & 708.75 & 815.751 \\
8 & 10.0 & 0.5 & 5.0 & 33 & 50 & 50.0 & 595.0 & 50.00 & 455.796 \\
\hline
\end{tabular}

Table 5. Modified Janbu's method of analysis at present condition (dry condition)

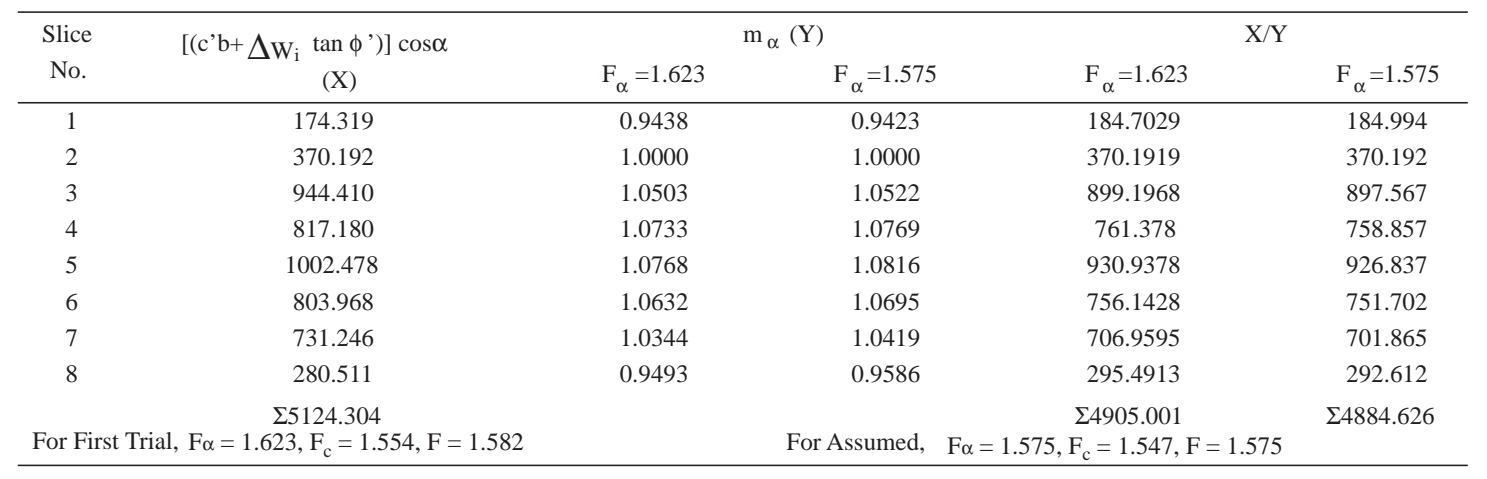

Table 6. Modified Janbu's method of analysis at fully saturated condition

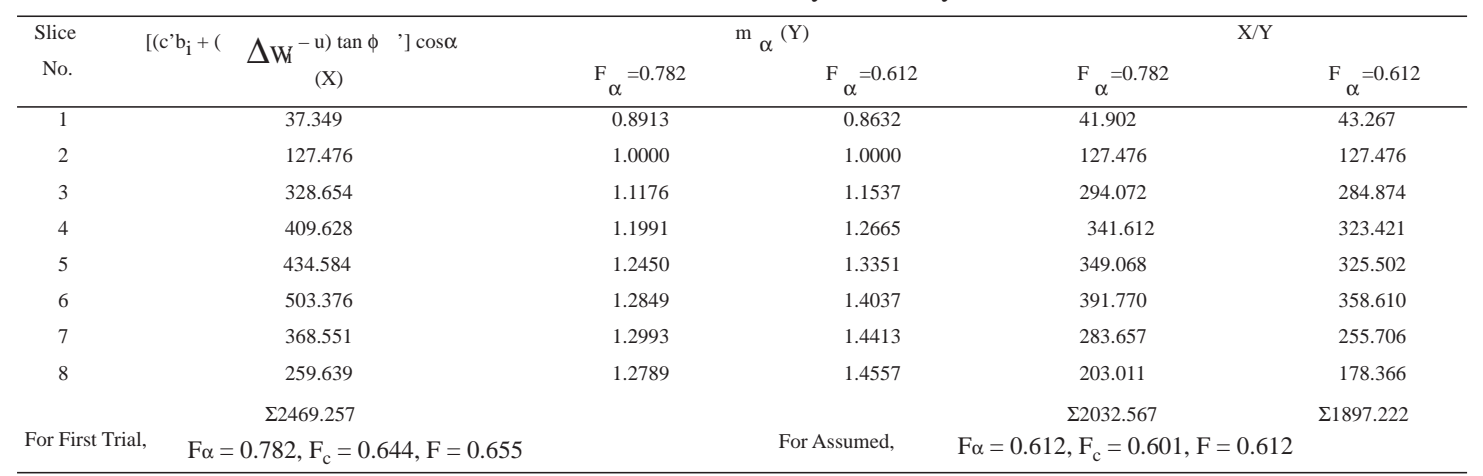

South-Central Nepal (July 19-20, 1993), ICIMOD, Kathmandu, pp.74.

Graham, J., 1984. Methods of Stability Analysis, Department of Civil Engineering, University of Manitoba, Slope Instability: In D. Brunsden and D.B. Prior (Eds), John Wiley \& Sons Ltd., pp. 171-215.
Manandhar, S., 2000. Engineering Geologic Studies of the Landslides in the Kulekhani Catchment, Central Nepal, Lesser Himalaya (unpublished), 130p.

Stöcklin, J., Bhattarai, 1981, Geology of Kathmandu Area and Central Mahabharat Range, Nepal Himalaya, New York, pp. 12-32. 